\title{
Refractory T-Cell Prolymphocytic Leukemia
}

National Cancer Institute

\section{Source}

National Cancer Institute. Refractory T-Cell Prolymphocytic Leukemia. NCI Thesaurus.

Code C157691.

T-cell prolymphocytic leukemia that is resistant to treatment. 